\title{
Diyabetli hastaların periferal nöropatik ağrı ile baş etme biçimleri: Nitel bir çalışma
}

\author{
Zehra Gök Metin', İsmail Emre Arslan² \\ ${ }^{1}$ Hacettepe Ü. Hemşirelik Fakültesi, İç Hastalıkları Hemşireliği AD., Ankara \\ ${ }^{2}$ Gazi Ü. Tıp Fakültesi, İç Hastalıkları AD., Endokrin Bilim Dalı, Ankara
}

Öz

Amaç: Bu çalışmanın amacı, diyabetli hastaların periferal nöropatik ağrı ile baş etme biçimlerini derinlemesine incelemektir. Yöntem: Bu tanımlayıcı nitel araștırmada, periferal nöropatik ağrılı 20 diyabet hastası ile yarı-yapılandırılmış görüşme rehberi kullanılarak yüz-yüze derinlemesine görüşmeler gerçekleştirilmiştir. Araştırma bir üniversite hastanesinin endokrin bölümü polikliniğinde yürütülmüştür. Görüşmeler kayıt altına alınmış ve transkript edilmiştir. Araştırma verileri, betimsel analiz tekniği ile ortaya çıkan tema ve alt temalar ile yorumlanmıştır. Bulgular: Araştırmaya dahil edilen hastaların yaş ortalaması 51.8 yıl olup, çoğunluğunu (\%66.6) kadınlar oluşturmuştur. Hastaların büyük kısmı (\% 90) Tip II diyabet tanısına sahipti. Nitel veri analizi ile ortaya çıkan temalar (1) hastalığa özgü kontrolleri gerçekleștirme; (2) sağlıklı yaşam biçimi davranışlarını sürdürme; (3) ağrının verdiği sınırlılıklar doğrultusunda günlük rutinleri tamamlamaya çalışma; (4) ağrıyı arttırabilecek durumlardan kaçınma (hızlı hareket etmeme, merdiven çıkmama, sigarayı bırakma, vb.); (5) ağrıya odaklanmama, dikkati farklı aktivitelere verme; (6) ağrının azalmasına katkıda bulunan aktiviteleri deneme (rahat ayakkabı seçme, ayakları uzatma, ayakları birbirine sürme, ayakları yıkama, masaj yapma, bitkisel ürün/yăg kullanma) şeklinde sıralanmıştır. Sonuç: Araştırma, endokrin polikliniğinde düzenli şekilde takip edilen diyabetli hastaların nöropatik ağrı ile baş etmede öncelikle tıbbi uygulamalara başvurduklarını ortaya çıkarmıştır. Bilişsel olarak ağrıyı uzaklaştırma, masaj, ovma gibi geleneksel uygulamalar, reçete edilmemekle birlikte bazı bitkisel ürünlerin kullanımı diğer baş etme biçimleridir. Bunlara rağmen, hastalar nöropatik ağrı ile yaşamanın zorlayıcı olduğunu bildirmiştir. Sağlık profesyonellerinin, ağrı yönetiminde etkinliği kanıtlanan uygulamalar konusunda bu hassas gruba danışmanlık vermesi gerekmektedir.

Anahtar kelimeler: Baş etme, diyabetik periferal nöropati, hasta, nitel çalışma, nöropatik ağrı

Yazının geliş tarihi:22.05.2017

Yazının kabul tarihi: 20.07.2017

Sorumlu Yazar: Yrd.Doç. Dr. Zehra Gök Metin, Hacettepe Üniversitesi Hemşirelik Fakültesi

İç Hastalıkları Hemşireliği Anabilim Dalı, E-posta: zehragok85@hotmail.com, Tlf: 031230515 $80 / 149$ 


\title{
Coping styles with peripheral neuropathic pain in diabetic patients: A qualitative study
}

\begin{abstract}
Aim: The aim of this study was to examine in depth coping styles in patients with diabetes. Method: In this descriptive and qualitative study, face-to-face in-depth interviews were conducted with 20 diabetic patients with peripheral neuropathic pain using a semi-structured interview guide. The study was carried out in the endocrine outpatient clinic of a university hospital. Interviews were recorded and transcribed. The data were interpreted by the themes and sub-themes that emerged with the descriptive analysis technique. Results: Mean age of the patients included in the study was 51.8 years and the majority (66.6\%) were women. Most of the patients (90\%) had Type II diabetes. Themes emerged from qualitative data analysis (1) performing disease specific controls; (2) maintaining healthy lifestyle behaviors; (3) attempting to complete daily routines in line with the limitations of pain; (4) avoiding situations that may increase pain (not moving fast, not climbing stairs, quitting smoking, etc.); (5) not focusing on pain, paying attention to different activities; (6) to try out the activities that contribute to the reduction of pain (choosing comfortable shoes, lengthening the feet, rubbing feet to each other, washing feet, massage, using herbal products or oils). Conclusion: Study findings have shown that diabetic patients regularly followed in endocrine outpatient clinic primarily seek medical advice when coping with peripheral neuropathic pain. Relieving pain cognitively, traditional applications such as massage and scrubbing, as well as the use of some herbal products along with not being prescribed are other ways of coping styles. Nonetheless, patients reported that living with neuropathic pain is a challenge. Health professionals should advise this sensitive group practices proven efficacy in pain management.
\end{abstract}

Key words: Coping with, diabetic peripheral neuropathy, qualitative study, neuropathic pain, patient

\section{Giriş}

Diyabetik periferal nöropati, diyabetin en önemli komplikasyonlarından biridir ve hastaların yaklaşık yarısına yakınında ortaya çıkmaktadır. Periferal nöropati gelişen hastaların ise yaklaşık \%40-60'ında nöropatik ağrı gelişmektedir.1-3 Hastalar, periferal nöropatik ağrıyı, alt ekstremitelerinde yangı, karıncalanma, uyuşma, elektrik çarpması, hissizlik gibi ifadelerle belirtmektedir. ${ }^{4,5}$ Yapılan araştırmalarda nöropatik ağrının ayak ülserleri ve ekstremite ampütasyonlarının önemli bir nedeni olduğu, hastaların fiziksel hareketlerinin kısıtlanmasına ve yaşam kalitesinin azalmasına neden olduğu bildirilmektedir.4-6 Fiziksel fonksiyonlardaki sinırlıklara ek olarak, ağrı nedeniyle hastalar uyku sorunlarl, sosyal aktivitelere dahil olamama ve iş yaşamında verimliliğin azalması gibi sorunlar deneyimlemektedir.4,7,8 $\mathrm{Bu}$ kisitlanmalara bağlı olarak, hastalar kendilerini dışlanmış ve işe yaramaz hissetmekte, depresyon, gerginlik, anksiyete ve geleceğe ilişkin önemli korkular yaşamaktadırlar.4,9,10

Günümüzde trisiklik antidepresanlar, selektif seratonin inhibitörleri, antikonvülsanlar ve alfa lipoik asit gibi antioksidanlara rağmen, nöropatik ağrının etkin tedavisi sağlanamamakta ve hastalar genelde tedaviden memnun olmamaktadırlar.11,12 Ayrıca hastalardaki semptom çeșitliliği ve tedavilere ilişkin verilen yanıtların farklı olması da nöropatik ağrının tedavisini zorlaştırmaktadır. Sürekli ağrı ile yaşama, kullanılan tedavilere rağmen etkin tedavi sağlanamaması gibi nedenler hastaları ağrı ile baş etme noktasında farklı arayışlara yöneltmektedir. $\mathrm{Bu}$ süreçte, hastalar ağrı yönetiminde kendi kendilerine bazı yöntemleri kullanarak ağrılarını hafifletmeye çalışmaktadır. ${ }^{13}$

Öte yandan, ağrının subjektif bir deneyim olarak tanımlanması, ağrıyı azaltan ve artıran faktörlerin bireylere göre değişmesi, ağrının algılanması ve 
yönetiminde de bireysel farklıkların önemli yer tutması dikkate alınması gereken diğer konulardır.14-20 Literatür incelendiğinde periferal nöropatik ağrısı olan diyabetli hastaların nöropatik ağrı ile bireysel baş etme stratejilerini inceleyen sinırlı sayıda çalışma bulunmaktadır.13 Tayvan'da Tip 2 diyabetli hastalarla odak grup görüșmeleri yoluyla yapılan tanımlayıcı-nitel bir çalışmada, hastaların sıklıkla bildirdikleri baş etme stratejileri; hareketi sürdürme, ne yapacağını bilememe, reçete dışı birtakım ürünler kullanma ve sağlık profesyonellerinden yardım isteme şeklinde ortaya çıkmıştır. ${ }^{13}$ Ülkemizde ise diyabetli hastaların nöropatik ağrı ile baș etme biçimlerini inceleyen nicel veya nitel herhangi bir araştırmaya rastlanmamıştır. $\mathrm{Bu}$ nedenle, karma ve doğal bir örneklemden oluşan (yaş, cinsiyet, diyabet tanı yılı, vb.) diyabet tanılı hastaların periferal nöropatik ağrı ile baş etme biçimlerini derinlemesine inceleyen ve hastaların bu ağrı ile baş etmede geliştirdikleri bireysel deneyimlerini hasta perspektifinden ele alan nitel araştırmalara gereksinim duyulmaktadır. $\mathrm{Bu}$ çalışmanın amacl, diyabetli hastaları periferal nöropatik ağrıyla baş etme biçimlerini bireysel görüşmeler yoluyla derinlemesine incelemektir.

\section{Gereç ve Yöntem}

\section{Araştırmanın tipi}

$\mathrm{Bu}$ tanımlayıcı-nitel araștırma; yarı yapılandırılmış görüşme tekniği kullanılarak yapılmıștır.

\section{Araştırmanın evreni ve örneklemi}

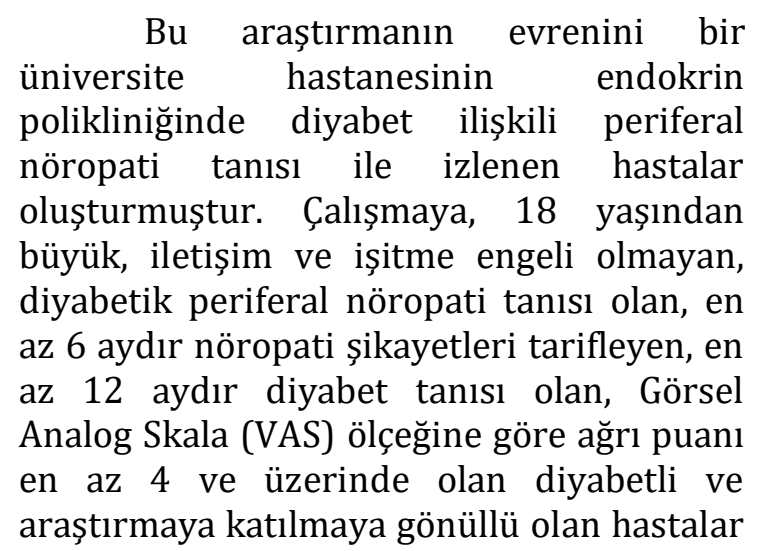

dahil edilmiștir. Psikiyatrik hastalık tanısı olan (bipolar, şizofreni, majör depresyon, intihar girişimi vb.), diğer nedenlere bağlı nöropatisi gelişen (kemoterapi ilişkili), ampütasyonu olan, yatağa bağımlı olan, ayakta aktif yarası olan ya da ekstremitelerinde ciddi periferik arter hastalığı olan ve araștırmaya katılmaya gönüllü olmayan bireyler dahil edilmemiştir. Araştırmanın yürütüldüğü poliklinikte kolay ulaşlabilir durum örneklemesi yoluyla dahil edilme kriterlerini karşılayan ve araştırmaya gönüllü olarak katılmayı kabul eden 32 hasta araștırmaya dahil edilmiștir. Sonrasında bu hastalarla yüz-yüze derinlemesine görüşmelere başlanmıștır. Veriler birbirini tekrar etmeye başlayıncaya kadar görüşmelere devam edilmiştir. Sonuç olarak, veri doygunluğuna ulaşıldığında görüşmelere son verilmiş ve araştırma 20 diyabetli hasta ile tamamlanmıştır.

\section{Verilerin toplanması ve analizi}

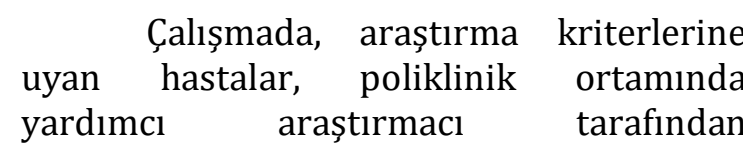
değerlendirilmiş, hastaların ağrı şiddeti VAS kullanılarak ölçülmüş ve araştırmaya katılmayı gönüllü olarak kabul eden hastalar sorumlu araştırmacıya yönlendirilmiştir. Sorumlu araștırmacı poliklinik ortamında hastalarla tanışmış, araştırmanın amacı ve uygulama adımları hakkında hastaları bilgilendirmiş, poliklinikte bulunan boş ve sessiz bir odada yüz-yüze bireysel görüşmeleri gerçekleştirmiştir. Sorumlu araștırmacl, araștırmanın yürütüldüğü poliklinikte hizmet vermeyen, farklı bir kurumda çalışan, araștırma örneklemi ile önceden herhangi bir bağlantısı olmayan ve doktora derecesine sahip bir akademisyendir. Sorumlu araştırmacı, Amerika'da doktora sonrası araştırmacı pozisyonundayken nitel araştırma yöntemlerine ilișkin farklı dersler almıș, bu derslere yönelik çok sayıda uygulama eğitimine katılmış ve farklı hasta gruplarıyla da nitel araștırmalar gerçekleştirmiştir. Ayrıca, dört yıla yakın süreyle klinik hemşiresi olarak görev yapmış, diyabet tanılı bireylere bakım vermiştir. Araştırmacl, her görüşme öncesinde 
araștırmanın amacını hastalara açıklamıştır. Görüşme sırasında bir rehber yardımı ile hastalara sorular yönlendireceğini ve hastaların diledikleri kadar konuşabileceklerini bildirmiștir. Görüşmelerin başında hastalarla sıcak bir ortam oluşturmak adına önce hasta-tanıtıcı özellikler formu doldurulmuş, sonrasinda ses kaydı eşliğinde görüşme rehberi yardımıyla hastaların periferal nöropatik ağrı ile baş etme biçimleri derinlemesine incelenmiștir. Yüz-yüze görüşmelere, verilerin doygunluğuna ulaşllana, veriler kendini tekrarlayana kadar devam edilmiş ve 20. görüşmede veri doygunluğuna ulaşılmıștır.

\section{Veri toplama formları}

Hasta-tanıtıcı özellikler formu: Araştırmacılar tarafından literatür taranarak geliştirilen tanıtıcı bilgiler formunda, hastaların yaș, cinsiyet, medeni durum, eğitim durumu, çalışma durumu, diyabet tanı alma süresi, diyabet tipi, periferal nöropati semptomlarının lokasyonu, periferal nöropatik ağrıya ilişkin aktif tedavi alıp almama durumları ve VAS ağrı düzeyi gibi bilgileri içeren toplam 10 soru yer almıștır.4,7,13

Görsel Ağrı Ölçeği (VAS): Görsel analog skala, kolay uygulanabilmesi, güvenli ve duyarlı olması nedeniyle kliniklerde ağrının değerlendirilmesi için en sık kullanılan yöntemlerden biridir. On santimetre uzunluğunda yatay bir çizginin üzerinde sol uçta" ağrım yok" sağ uçta ise "ağrım var" tanımları bulunur. Hastaya bu çizgi üzerinde, kendi ağrı şiddetini en iyi ifade edecek noktayı işaretlemesi söylenir. Hastanın işaretinin sol uca olan uzaklığı ölçülür. Genellikle milimetre şeklinde ölçülen bu uzaklık, "puan" şeklinde yorumlanır. ${ }^{21}$ VAS, araştırmamızda yardımcı araştırmacl tarafindan hastaların araștırmaya dahil edilmesi sürecinde kullanılmış, ağrı puanı 4 ve üzerinde olan hastalar araştırmaya katılım açısından değerlendirilmiştir.

Görüşme rehberi: Hastaların yaşadıkları ağrı ile nasıl baş ettiklerini, hangi yöntemleri uyguladıklarını ve ağrıyı hafifletmede kendilerine iyi gelen yöntemlerin hangilerinin olduğunu sorgulayan yarıyapılandırılmış görüşme rehberi yardımıyla "Bana bu konuda daha fazla bilgi verebilir misiniz?", "Konuyu biraz daha açabilir misiniz?" veya "Burada tam olarak neyi anlatmak istediniz?" gibi açlk uçlu sorular yönlendirilerek konu derinlemesine incelenmeye çalışılmıştır. Görüşmeler 35-65 dk. arasında sürmüştür ve ses kayıt cihazı ile kayıt altına alınmıştır.

Araştırmanın yapılabilmesi için Hacettepe Üniversitesi Girişimsel Olmayan Etik Kurul Başkanlığı'ndan gerekli etik kurul izni alınmıştır (GO 17/422-24).

\section{Verilerin analizi}

Tanıtıcı bilgiler formundaki verilerin analizinde SPSS 23 versiyonu kullanılmış ve tanımlayıcı istatistiklerden (yüzde, ortalama, standart sapma, min-maks değerleri) yararlanılmıştır. Yüz-yüze görüşmelerden elde edilen nitel veriler, öncelikle sorumlu araştırmacı tarafından her görüşme sonrası teker teker transkript edilmiş ve okunmuştur. Sonrasında transkriptler yardımcı araştırmacı tarafından da okunmuştur. Verilerin analizinde betimsel analiz tekniği kullanılmıştır. Betimsel analiz tekniği ile veriler tema ve alt temalara ayrılmış ve yorumlanmıștır. ${ }^{22,23}$ Tema ve alt temalarla ilgili, herhangi bir farklılık oluştuğunda, iki araştırmacı transkriptleri birlikte değerlendirmiş ve ortak karara varmışlardır.

\section{Bulgular}

Hastaların tanıtıcı özelliklerine ilişkin bulgular

Araştırmaya dahil olan hastaların yaş ortalaması 51.8 yıl olup, 32-68 yaş arasında dağılım göstermiștir. Hastaların diyabet tanı süre ortalaması 12.1 yıl, VAS ağrı skor ortalaması ise 6.5 olarak hesaplanmıștır. Çalışmaya dahil olan hastaların çoğunluğunu (\%66.6) kadınlar olușturmuștur. Hastaların büyük bir bölümü evli (\%80) ve ilköğretim mezunu (\%40) olup, yarısı ise (\%50) çalışmıyordu. Hastaların tamamının hem el hem de ayaklarında periferal nöropatik ağrı şikayeti 
bulunmaktaydı. Hastaların sadece dört tanesi (\%20) nöropatik ağrıya yönelik ilaç kullanmiyordu (Tablo 1).

Tablo 1. Hastaların tanıtıcı özellikleri $(n=20)$

\begin{tabular}{|c|c|c|}
\hline $\begin{array}{l}\text { Tanıtıcı } \\
\text { özellikler }\end{array}$ & Ortalama $\pm S D$ & Aralık \\
\hline Yaş (yil) & $51,8 \pm 9,1$ & $32-68$ \\
\hline Diyabet tanı & $12.1 \pm 8.8$ & $1-28$ \\
\hline süresi (yll) & & \\
\hline \multirow[t]{2}{*}{ VAS ağrı şiddeti } & $6.5 \pm 1.3$ & $4-9$ \\
\hline & $\mathrm{n}$ & $\%$ \\
\hline \multicolumn{3}{|l|}{ Cinsiyet } \\
\hline Kadın & 12 & 66.6 \\
\hline Erkek & 8 & 33.4 \\
\hline \multicolumn{3}{|l|}{ Medeni durum } \\
\hline Evli & 16 & 80.0 \\
\hline Bekar & 4 & 20.0 \\
\hline \multicolumn{3}{|l|}{$\begin{array}{l}\text { Çalışma } \\
\text { durumu }\end{array}$} \\
\hline Tam zamanlı & 6 & 30.0 \\
\hline Yarı zamanlı & 4 & 20.0 \\
\hline Çalışmıyor & 10 & 50.0 \\
\hline \multicolumn{3}{|l|}{ Eğitim düzeyi } \\
\hline İlköğretim & 8 & 40.0 \\
\hline Lise & 7 & 35.0 \\
\hline Üniversite & 5 & 25.0 \\
\hline \multicolumn{3}{|l|}{ Diyabet tipi } \\
\hline Tip I & 2 & 10.0 \\
\hline Tip II & 18 & 90.0 \\
\hline \multicolumn{3}{|l|}{$\begin{array}{l}\text { Nöropati } \\
\text { semptomlarının } \\
\text { yeri }\end{array}$} \\
\hline Eller ve ayaklar & 20 & 100.0 \\
\hline \multicolumn{3}{|l|}{ Nöropatik ağrı } \\
\hline \multicolumn{3}{|l|}{$\begin{array}{l}\text { için tedavi alma } \\
\text { durumu }\end{array}$} \\
\hline Evet & 16 & 80.0 \\
\hline Hayır & 4 & 20.0 \\
\hline
\end{tabular}

Hastaların periferal nöropatik ağrı ile baș etme biçimlerine yönelik ortaya çıkan tema ve alt temalar

Verilerin analizi sonrası ortaya çıkan altı tema ve bu temalara ilişkin alt temalar Tablo 2'de sunulmuştur.

\section{Tema 1. Hastalığa özgü uygulamaları ve kontrolleri gerçekleştirme}

Hastaların büyük kısmı ilaçlarını hiç kesintiye uğratmaksızın kullandıklarını $(\mathrm{n}=16)$, hekim kontrollerini aksatmamaya çalıştıklarını $(\mathrm{n}=14)$, daha detaylı incelenip, sorgulandıkları için üniversite hastanesine gitmeye $(n=12)$ özen gösterdiklerini ve düzenli aralıklarla kan şekerlerini kontrol ettiklerini $(n=10)$ bildirmişlerdir.

"Şeker ilaçlarını kullanmamaya uzun zaman direndim ama baktım başka çare kalmiyor, sonunda kabullendim ve istisnasız hiç aksatmadan ilaçlarımı kullanıyorum artık."

"Doktorumun verdiği ilaç ve insülin dışında hiçbir şey kullanmıyorum."

"Doktorum bu ağrılarım için beni nöroloji bölümüne gönderdi, en son bir ilaç başladılar, onu kullanmaya başladım."

"Eğer ağrı çok rahatsız ediyor ve hareketlerimi kısitllyorsa o zaman mecbur ilaçlarımı kullanıyorum."

"Ağrı olduğu gün, bir an evvel ilaçlarımı alıyorum. Hemen kan șekerime bakıyorum, yine mi yükseldi diye. Şekerim yüksek de çıksa düşük de çıksa ağrımaya devam ediyor."

"Ağrılarım çok aşırı olursa, işte o zaman ağrı kesici almayı tercih ediyorum."

"Ağrılarımı ilk başta anlamıyordum, dayanılmaz hale gelince doktoruma gittim, bunun sinirlerden kaynaklandığını söyledi. Bazen dayanamayacak hale geliyorum, ağrı kesicilerle idare etmeye çalışıyorum."

"Yani ne bileyim, genelde ağrı kesici kullanmayı tercih ediyorum." 
Tablo 2. Hastaların baş etme biçimleri ile ilgili ortaya çıkan temalar ve alt temalar ( $n=20)$

\begin{tabular}{|c|c|}
\hline Temalar & Alt temalar \\
\hline \multirow{5}{*}{$\begin{array}{l}\text { 1. Hastalığa özgü uygulamaları ve } \\
\text { kontrolleri gerçekleştirme }\end{array}$} & 1.1. Kesintiye uğratmaksızın ilaçlarını düzenli kullanma \\
\hline & 1.2. Hekim kontrollerini aksatmama \\
\hline & 1.3. Düzenli aralıklarla kan şekerini kontrol etme \\
\hline & 1.4. Üniversite hastanesini tercih etme \\
\hline & 1.5. Ağrıya dayanamadığında analjezik kullanma \\
\hline \multirow{4}{*}{$\begin{array}{l}\text { 2. Sağlıklı yaşam biçimi davranışlarını } \\
\text { sürdürme }\end{array}$} & 2.1. Sağlıklı beslenmeye devam etme \\
\hline & 2.2. Düzenli egzersiz yapmaya çalışma \\
\hline & 2.3. Hareket etmeye çalışma \\
\hline & 2.4. Sigarayı bırakma \\
\hline \multirow{3}{*}{$\begin{array}{l}\text { 3. Ağrının verdiği sınırlılıklar } \\
\text { doğrultusunda günlük rutinleri } \\
\text { tamamlamaya çalışma }\end{array}$} & 3.1. Günlük işlerin bir kısmını erteleme \\
\hline & 3.2. Günlük ișleri yavaș yavaș yapma \\
\hline & 3.3. Hayattan zevk almaya çalışma \\
\hline \multirow{5}{*}{$\begin{array}{l}\text { 4. Ağrıyı arttırabilecek durumlardan } \\
\text { kaçınma }\end{array}$} & 4.1. Uzun yolculuklara çıkmama \\
\hline & 4.2. Aşırı yemekten kaçınma \\
\hline & 4.3. Çok fazla yürümeme \\
\hline & $\begin{array}{l}4.4 \text { Uzak yerlere giderken otobüs yerine uçak tercih } \\
\text { etme }\end{array}$ \\
\hline & 4.5. Merdiven çıkmaktan ve yük taşımaktan kaçınma \\
\hline \multirow{4}{*}{$\begin{array}{l}\text { 5. Ağrıya odaklanmama, dikkati farklı } \\
\text { yönlere çekecek aktivitelere katılma }\end{array}$} & 5.1. Ağrıyı düşünmemeye çalışma \\
\hline & 5.2. Ağrıya öncelik vermeme \\
\hline & 5.3. Kadınlar lokaline kayıt olma \\
\hline & 5.4. Yüzme \\
\hline \multirow{5}{*}{$\begin{array}{l}\text { 6. Ağrının azalmasına katkıda bulunan } \\
\text { aktiviteleri deneme }\end{array}$} & 6.1. Yorgun hissedince ayakları uzatma ve rahatlama \\
\hline & 6.2. Evdekilerden ayaklara masaj yapmalarını isteme \\
\hline & 6.3. Rahat ayakkabılar giyme \\
\hline & 6.4. Ayakları birbirine sürtme \\
\hline & 6.5. Ayak ve ellere yağ, krem vb. ürünler sürme \\
\hline
\end{tabular}


Tema 2. Sağlıklı yaşam biçimi davranışlarını sürdürme

Hastaların büyük bölümü, hekim ve diyetisyen tavsiyelerine dikkat ettiklerini, düzenli egzersiz yapmaya çalıştıklarını, diyetlerine-sağlıklı beslenmeye dikkat ettiklerini ve kilo vermeye çalıştıklarını, bunlara uyum göstermenin ağrılarını azaltmada kendilerine yarar sağladığını ifade etmiștir.

"Ayaklarımdaki ağrı nedeniyle, ağır sporlar yapamıyorum. Ancak düzenli șekilde yürümeye çalışıyorum. Ama koşamıyorum. Her gün otobüsten evime iki durak kala iniyorum, mutlaka yürümeye gayret ediyorum. Doktorum da yürümemi istedi. Tek yapabildiğim bu."

"Kan şekerim yüksek gitmeye başladı bir ara, doktorum beni diyetisyene gönderdi. 0 da bana neler yediğimi sordu. Ben de her gün pirinç pilavı yediğimi söyledim. Bunun üzerine, bu kadar sık pilav yeme, kan şekerin yüksek gider dedi. 0 gün bugündür yediğim her şeye dikkat ediyorum, kendimi pirinç pilavından soyutladım, iş yerinde diyet yemeği alıyorum. Meyve, yeşillik yiyoruz hanımla, çocuklarla."

"Bundan altı ay önce, elimde tırnaklarımın dibinde küçük küçük yaralar çıkmaya başladı. Doktoruma gittim, kan tahlili yaptı, üç aylık kan șekerimin çok yüksek olduğunu, insülin başlayacağını ve diyet yapmam gerektiğini söyledi. Eşimle birlikte bizi diyetisyene gönderdi. Altı ayda sekiz kilo verdim, hamur işi, kızartma yemiyorum artık. Ellerimdeki yaralar kayboldu, ağrılarım da hafifledi çok şükür."

"Beslenmeme dikkat ediyorum tabi. Etrafımdaki herkes bana hayran olur, düzenli besleniyorum diye. Ağrılarla birlikte kendimi tatlllardan özellikle korumaya başladım. Baklava alsak, tüm dilimi yiyemem, o üstündeki ince kattan alırım sadece, nefsim körelsin diye, çok şerbetliyse bir kere alırım, ikinciyi ısırmam. Bazen derim ki kendime: neler yedi bu diş, ne altın oldu ne gümüş. Ben bunu yiyince bir artım olmayacak, zarar yani. Sabahları iki dilim ekmek, yumurta gibi hafif şeylerle kahvaltı ediyorum."
Tema 3. Ağrının verdiği sınırlılıklar dahilinde günlük rutinleri tamamlamaya çalıșma

Görüşmelerin çoğunda, hastalar sahip oldukları nöropatik ağrıya rağmen, günlük yaşamlarını sürdürmeye çalıştıklarını, rutinleri yapmaya çalışırken, ellerindeki işi yarım bırakma, erteleme, yavaş yavaş tamamlama veya birilerinden destek alma, çok yorulmamaya çalışma gibi bir takım uygulamaların ağrılarını hafifletmede etkili olduğunu bildirmiştir.

"Sabah kalktığımda çok ağrım oluyor, inanır misın yataktan kalkacak gücüm olmuyor. Ama ne yaparsın, ev hanımıyım, mecburum, eşim var, çocuklarım bir taraftan. İyi kötü kalkıyorum, işlerin ucundan tutuyorum, bir süre sonra sabahki gibi sızlamıyor, işleri bitireyim, temizlikti, yemekti derken, akşam oluveriyor."

"Benim en çok ayakta uzun süre kaldığımda ayaklarım zonkluyor. Ben de mecbur evde çoğu işimi oturarak yapıyorum. Mesela mutfakta yemek yaparken, masanın üstüne malzemelerimi koyuyorum, sandalyede saatlerce ağır ağır tamamlıyorum işlerimi. Oturunca biraz hafifliyor, yorulmadan elimin yettiğince yapıyorum işte öyle."

"Ah kızım ah, eskiden ben böyle miydim, bırak kendimi, eşime, dostuma herkese yardım ederdim, temizliğe koșardım. Şimdi elim kolum kalkmıyor. Ev işlerimi yetiştiremiyorum. Ben de ne yapayım, bir gün yemek, ertesi gün evi süpürüyorum. Bazen de hiç yapmıyorum. Büyük temizliğe de kadın çağırmaya başladım. Yorulunca, ayakta kalınca ağrım çok oluyor. Gücüm yettiğince yapıyorum."

Tema 4. Ağrıyı arttırabilecek durumlardan kaçınma

Hastaların büyük çoğunluğu ortak olarak, ağrı nedeniyle yaşadıkları fiziksel kısıtlanmaları bildirmiş, özellikle yürüme, yük taşıma, hızlı hareket etme ve merdiven çıkma gibi aktivitelerden kaçınarak ağrılarını hafif düzeyde tutmaya çalıştıklarını belirtmişlerdir.

"Yolda yürümeyi istemiyorum mesela. Mesela arabasız bir yere gitmek istemiyorum. Oğlumun arabası var, sağ olsun onu çağırıyorum, birlikte gidiyoruz. 
Yürüdügüm zaman sanki ayağımın altında diken var, canımı yakıyor. Ben de ne yapayım, araba yoksa evden çlkmamaya çalışıyorum. Uzak yoldan, merdivenden kaçınıyorum. Mutfağa gidip gelmek bile zor geliyor, çaydanlığı yanıma getiriyorum."

"Azcık bir yük, market poşeti taşısam, hemen ellerim uyuşuyor. Ben de mümkün olduğunca yükten uzak kalıyorum. Olursa eve ekmek, gazete alıyorum hepsi bu. Ağır taşısam ağrıdan sızlanmaya başlıyorum, bu sefer evdekiler de bana kiziyor."

"Ben hastanede getir götür işlerine bakıyorum. Ama elimde yük olunca, yürümek daha çileli geliyor. Ben de artık elimdekilerin hepsini asansöre koyuyorum, eğer kat çıkacaksam da mecburen asansörü bekliyorum. Böyle olunca, en azından eve varınca ayaklarım çok ağrımıyor."

Tema 5. Ağrıya odaklanmama ve dikkati farkı yönlere verme

Araştırmaya dahil edilen hastalar, ağrı ile yaşamanın kendileri için rutin bir hale geldiğini, bununla savaşmanın ya da reddetmenin mümkün olmadığını, bu durumu kabullenmenin gerekliliğini ve ağrıyı düşünmemenin, dikkati başka uğraşlara vermenin ağrıyla baş etmede olumlu katkılar sağladığını ifade etmiştir.

"Ağrılarımı unutmaya çalışıyorum. Yani şeker hastası olduğumu aklıma getirmemeye çalışıyorum. Psikolojik olarak kendimi sıkıntıya sokmuyorum. Ben de şeker yok gibilerinden."

"Hani böyle başa çıkma değil de, benim acl eşiğim biraz yüksek galiba. Açıkçası ağrıyor, acıyor diye kendime çok şey yapmıyorum. Hani bu ağrı kesicilerle filan geçebilecek bir şey değil. Ben iyiyim, hasta değilim gibi kendimi telkin etmeye çalışıyorum."

"Benim eşim de şeker hastası, kışın çocuğun okulu var, mecbur onu bekliyoruz. Ama okullar tatil olunca, memlekette küçük bir bahçemiz var oraya gidiyoruz. Kendimizi çok yormadan, biraz bağ-bahçe işi yapıyoruz. İkimize de çok iyi geliyor. Eş, dost, akraba, komşularımız geliyor, sohbet, çay derken, hastalıktı, ağrıydı, insülindi hiç aklıma gelmiyor. Yazları rahatım, ama kışın buradaki eve dönünce yapacak bir şey olmayınca ağrılarıma odaklanıyorum, günlerim sıkıntılı geçiyor."

"Artık bu ağrının benle birlikte devam edeceğini biliyorum, kendimi buna alıştırdım, yapacak bir şey yok. Kafamdan silmeye çalışıyorum, takmamaya çalışıyorum."

"Ağrılarımı geçirmek için hanımlar lokaline kayıt oldum. Yüzme dersi aldım, kapalı havuza gittim, spor yapmaya, aklımı başka şeylere vermeye çalışıyorum. Evdeki işlerden boşluk buldukça, elimi, kafamı meşgul edecek şeyler buluyorum, bana iyi geliyor."

"Ben ağrılarıma çok alıştım. Biraz Polyanna'ya benzerim. Ağrılarımdan şikayet etmeyi hiç sevmem. Ben şeker hastasıyım bile demiyorum daha doğrusu. 0 , benimle yaşayan bir şey..."

\section{Tema 6. Ağrının azalmasına katkıda bulunan} aktiviteleri deneme

Hastaların birçoğu, ayaklarındaki ağrıları hafifletmek için kendi kendilerine denedikleri bir takım uygulamalar kullandıklarını ifade etmişlerdir. Bunlar, reçete dışı kullanılan bitkisel ürünler, yağlar, ayak masajı veya ayağı ovdurma, ayakları birbirine sürtme, ayağa soğuk su uygulama, geniş ayakkabılar kullanma ve ayak kan dolaşımını artırmaya yarayan birtakım ekipmanları kullanma şeklinde sıralanmıştır.

"Geceleri rahatlamak için melisa, papatya gibi bitki çayları içiyorum."

"Genellikle bitkisel ürünleri seviyorum. Mesela evde kantoron ve biberiye yağım var. Bazen onlarla evdekilere ayaklarımı ovduruyorum, bazen de kendim ovuyorum."

"Geçenlerde ayaklarımın altında korkunç derecede ağrı hissettim. Çok fazla yürüdügümde ayağımın altının şiştiğini, acıdığını ve kızardığını hissettim. Arkadaşım önermişti. Özel bir ayak merkezine gittim ve masaj yaptırmaya başladım. Vakit buldukça haftada 1-2 defa gitmeye çalışıyorum. 
Ayaklarımın ve bacaklarımın ağrısı biraz da olsa hafifliyor."

"Oğlum bana bir cihaz almıștı. Tekne gibi, içinde yuvarlak yuvarlak taşlar var. İçerisine su koyuyorsun belli bir seviyeye kadar, yarım saat çalıştırıyorsun. Bu cihaz, ayaktaki kanın dolaşmasını sağlıyormuş, kullanınca ayaklarımdaki ağrı hafifliyor."

"Çok yürüdüğüm günler, sanki keskin kaya üzerinde gezinmişim gibi geliyor, ayaklarım alev alev yanıyor. Hemen çorabımı çıkarıp, ayaklarımı soğuk suya tutuyorum, beni biraz ferahlatıyor."

"Ağrılarım çok arttığı zaman, evdekilere ayaklarımın altına bir takım masajlar yapmalarını rica ediyorum, genelde oğlum bana yardımcı oluyor, onlardan yardım almak gibi ara çözüm arayışlarım oluyor. Bunlar, geçici olarak fayda sağlasalar bile, ertesi gün aynı şekilde tekrar etmeye başliyor."

"Ayaklarımda çok ağrı olduğu zamanlarda, ayaklarımı birbirine sürterek, kendi kendime masaj yapar gibi yorganın altında, eşimi çok rahatsız etmeden ağrımı azaltma gayreti içerisine giriyorum. Ve ağrımı bir șekilde hissetmeyip, tekrar uyumaya çalışıyorum geceleri uyandığımda."

"İşte, hareket etmeye çalışıyorum kendimce. Fizik tedavi hareketlerim var, onları yapmaya çalışıyorum evde."

"Ayakkabılarımı genişletiyorum, kullanılmış ayakkabıları tercih ediyorum, mümkün olduğunca yeni ayakkabı almıyorum. Çocuklarımın ayakkabılarını kullanıyorum, geniș olmasına özen gösteriyorum. Otobüsle seyahat etmiyorum mesela, uzun seyahatlerde uçak kullanıyorum. İlla arabayla gidecek olursak da araçtan inerek mola veriyorum, biraz geziniyorum, ayaklarımı rahatlatmaya çalışıyorum."

\section{Tartışma}

$\mathrm{Bu}$ araştırmada, diyabetli hastaların periferal nöropatik ağrı ile baş etme biçimleri derinlemesine incelenmiştir. Hastalarla derinlemesine yapılan yüz-yüze görüşmelerden öne çıkan bulgular, sağlık profesyonellerinin öneri ve uygulamalarını yerine getirme, sağlıklı yaşam biçimi davranışlarını benimseme, ağrıya rağmen günlük yaşam aktivitelerini yerine getirmeye çalışma, ağrıyı arttıracak durumlardan kaçınma ve ağrıyı hafifletebilecek uygulamaları deneme şeklinde sıralanmıştır.

Araştırmamıza dahil olan hastaların büyük çoğunluğu, ağrı ile baş etmede sağlık profesyonellerinin kendilerine önerdiğ uygulamaları yerine getirdiğini, ilaçlarını kesintisiz kullandıklarını, doktor kontrollerine düzenli şekilde gittiklerini, kan şekerlerini kontrol ettiklerini ve ağrı dayanılmaz hale geldiğinde ağrı kesici ilaçlar kullandıklarını bildirmişlerdir. $\mathrm{Bu}$ bulgulardan hareketle, hastaların çoğu tedaviye uyum ve kan şekeri regülasyonunun nöropatik ağrının hafifletilmesinde yararlı olduğunu düşünmektedir. Jane ve ark. ${ }^{13}$ periferal nöropatik ağrısı olan diyabetli hastalarla yaptıkları tanımlayıcı-nitel bir çalışmada, hastaların ağrı ile baş etmek için doktorlarını ziyaret ettiklerini, eczaneden analjezik aldıklarını ve Çin tıbbı uygulamalarından olan akupunktura başvurduklarını bildirmişlerdir. Diğer çalışmalarda da hastaların büyük kısmı ağrı ile baş etmede doktora başvurduklarını ve analjezik kullandıklarını belirtmişlerdir. ${ }^{24-27}$ Araştırmamıza dahil olan hastaların düzenli sağlık kontrollerine gelmesi, nöropatik ağrı ile baş etmede kanıta dayalı-doktor önerilerine uygun şekilde hareket etmenin önemli bir açılklaması olabilir. Öte yandan düzenli kontrollere gelmeyen hastaların ağrı ile baş etmede geliştirdikleri farklı yaklaşımlar olabileceği de göz önünde bulundurulmalıdır.

Çalıșmada hastaların büyük bir bölümü, hekim ve diyetisyen tavsiyelerine dikkat ettiklerini, düzenli egzersiz yapmaya çalıștıklarını, diyetlerine-sağlıklı beslenmeye dikkat ettiklerini, kilo vermeye çalıştıklarını ve bunlara uyum göstermenin ağrılarını azaltmada kendilerine yarar sağladığını ifade etmiștir. Benzer șekilde Lansbury' nin ${ }^{17}$ kronik ağrılı yaşlı hastalarla yaptığı nitel bir çalışmada da hastaların 
kendilerine reçete edilen ilaçları kullandıkları, egzersiz ve fizyoterapi uygulamalarını yaparak ağrılarını hafifletmeye çalıştıkları bulunmuştur.

Araştırma bulgularımızdan öne çıkan temalardan biri, ağrının artmasına neden olabilecek durumlardan kaçınmadır. Hastalarımızın büyük çoğunluğu ortak olarak, ağrı nedeniyle yaşadıkları fiziksel kısıtlanmaları bildirmiş, özellikle yürüme, yük taşıma, hızlı hareket etme ve merdiven çıkma gibi aktivitelerden kaçınarak ağrılarını hafif düzeyde tutmaya çalıștıklarını belirtmișlerdir. Bu durumu destekler şekilde, hastaların çoğu nöropatik ağrıya rağmen, günlük yaşamlarını sürdürmeye çalıștıklarını, rutinleri yapmaya çalışırken ellerindeki işi yarım bırakma, erteleme, bu işleri tamamlamak için birilerinden destek alma ve çok yorulmama gibi bir takım uygulamaların ağrılarını hafifletmede etkili olduğunu bildirmiştir. Hastalar, gün içinde ayakta uzun süre kalmamaya ve işlerini oturarak tamamlamaya çalıştıklarını ifade etmiştir. Brod ve ark.'nın 4 diyabetik nöropatisi olan hastalarla yaptıkları başka bir nitel çalışmada da, ilk tema hastaların ağrı nedeniyle fiziksel hareketlerinin kısıtlanması olarak rapor edilmiștir. Çalışmamızda da hastalar, fiziksel kısıtlılıklarına rağmen günlük rutinlerini sürdürmenin, kendilerini rahatlattığını, hala işe yaradıklarını düşünmeyi sağladığını ve böylelikle ağrının etkisini daha az hissettiklerini bildirmişlerdir. ${ }^{25,28}$

Hastaların nöropatik ağrı ile baș etme biçimleri açısından bir diğer önemli tema, ağrıyı arka plana alma ve ağrıya odaklanmamadır. Hastalar ağrı ile yaşamanın kendileri için rutin bir hale geldiğini, ağrıyı kabullenmenin gerekliliğini ve ağrıyı düşünmemenin, dikkati başka uğraşlara vermenin ağrıyla baş etmede olumlu katkılar sağladığını ifade etmiştir. Benzer şekilde, Lansbury'nin ${ }^{17}$ kronik ağrılı yaşlı hastalarla yaptığı nitel çalışmada da, hastalar herhangi bir eğitim almadan kendikendilerine geliştirdikleri, sosyal kulüplere kayıt olma, komşuları ziyaret etme, müzik dinleme, dua etme ve espri-mizah yapma gibi davranışların ağrıları ile baş etmede kendilerini desteklediğini bildirmiştir. Diğer çalışmalarda da hastalar kötü ruh halinden kurtulmaya çalıştıklarını ve dikkatlerini farklı yöne verdiklerini ifade etmiş̧lerdir.13,24-26 Çalışmamızda hastalar melisa-papatya gibi bitkisel çaylar içme, ayaklara kantoron, biberiye gibi yağlar sürme, ovma ve masaj gibi uygulamalar, ayağı soğuk suyla yıkama, sürekli hareket etme, geniş ayakkabılar giyme ve ayak kan dolaşımını arttırmaya yarayan cihazlar gibi ağrılarını hafifletmede etkili olan yöntemler kullandıklarını bildirmişlerdir. Jane ve ark. ${ }^{13}$ çalışmasında da bulgularımızı destekler şekilde, hastalar nöropatik ağrılarını hafifletmek için yürüdüklerini, topuklarını sürekli kendi etrafında çevirerek hareketli kalmaya çalıştıklarını, egzersiz, masaj, ovma, ayak üstüne dokunma gibi hareketler yaptıklarını, balzam, kremler, bitkisel karışımlar ve nane yağı gibi reçete edilmeyen tamamlayıcı ürünleri ayaklarına sürdüklerini, sıcak su ile ayaklarını yıkadıklarını veya ayağı sıcak tutmak için çoraplar giydiklerini bildirmişlerdir. Ayrıca, ağrı ile baş etme biçimlerini inceleyen diğer çalışmalarda da sıcak-soğuk uygulama, masaj, dinlenme, egzersiz önde gelen baș etme biçimleri olarak rapor edilmiştir. ${ }^{24,25,27}$

Araştırma verileri endokrin polikliniğine düzenli şekilde takibe gelen hastalarla, bir sağlık profesyonelinin yaptığ derinlemesine görüşmeler ile elde edilmiştir. Görüşmeleri yapan kişinin sağlık profesyoneli olması, hastaların bireysel baş etme stratejilerini ifade etmelerinde yanlılığa neden olmuş olabilir. Kısıtlılıklarla birlikte, araştırmamızda diyabetli hastaların periferal nöropati ile baş etmek için öncelikle tıbbi uygulamalara başvurdukları ortaya çıkmıștır. Bunun yanında, hastalar ağrılarını hafifletmede etkili olduklarına inandıkları bir takım uygulamalar kullandıklarını bildirmişlerdir. $\mathrm{Bu}$ uygulamaların çoğunun ağrının artmasına engel olmak veya ağrıyı hafifletmek için yapıldığı dikkat çekmektedir. Hastaların çoğu, ağrıya rağmen hareketli olmaya çalıștıklarını, bilişsel olarak ağrıyı uzaklaştırmak istediklerini, masaj, ovma gibi ayaktaki ağrıya iyi gelen geleneksel uygulamaları kullandıklarını, reçete edilmemekle birlikte bir takım bitkisel 
ürünlerden

bildirmişlerdir.

faydalandıklarını

Diğer çalışmalarda nöropatik ağrıyla baş etmede kullanılan bireysel stratejilere benzer şekilde, çalışmamızdaki hastaların da temelde tıbbi uygulamalara önem verdikleri, bunun yanında kendi kendilerine deneyerek yarar sağladıklarını düşündükleri bir takım stratejiler geliştirdikleri görülmüştür. Buna rağmen, hastaların büyük kısmı bu ağrı ile yaşamanın zorlayıcı olduğunu ve ağrılarının tam olarak geçmediğini bildirmiştir. Sağlık profesyonelleri olarak, ağrı yönetiminde etkinliği kanıtlanan uygulamalar konusunda bu hassas gruba danışmanlık verilmesi, her birinin bireysel düzeyde ele alınması ve desteklenmesi gerekmektedir.

Çıkar çatışması: Yazarlar herhangi bir çıkar çatışması bildirmemiştir.

Finansal destek: Çalışmanın yürütülmesinde herhangi bir finansal destek alınmamıştır.

Teşekkür: Çalışmanın gerçekleştirilmesi için değerli katkıları olan, yüz-yüze görüşme ve ses kaydı işlemini kabul eden hastalarımıza sonsuz teşekkürlerimizi sunariz.

\section{Kaynaklar}

1. Lee C.C., Perkins B.A., Kayaniyil S., Harris S.B., Retnakaran R., Gerstein H.C., Zinman B., Hanley A.J. Peripheral neuropathy and nerve dysfunction in individuals at high risk for type 2 diabetes: the PROMISE cohort. Diabetes Care 2015;38(5):793-800.

2. Kim S.S., Won J.C., Kwon H.S., Kim C.H., Lee J.H., Park T.S., Ko K.S., Cha B.Y. Prevalence and clinical implications of painful diabetic peripheral neuropathy in type 2 diabetes: results from a nationwide hospital-based study of diabetic neuropathy in Korea. Diabetes Research and Clinical Practice 2014;103(3):522-529.
3. Reed C., Hong J., Novick D., Lenox-Smith A., Happich M. Incidence of diabetic peripheral neuropathic pain in primary care-a retrospective cohort study using the United Kingdom General Practice Research Database. Pragmatic and Observational Research 2013;4:27-37.

4. Brod M., Pohlman B., Blum S.I., Ramasamy A., Carson R. Burden of illness of diabetic peripheral neuropathic pain: a qualitative study. The Patient-Patient-Centered Outcomes Research 2015; 8(4): 339-348.

5. Davies M., Brophy S., Williams R., Taylor A. The prevalence, severity, and impact of painful diabetic peripheral neuropathy in type 2 diabetes. Diabetes Care 2006;29(7):1518-1522.

6. Argoff C.E., Cole B.E., Fishbain D.A., Irving G.A. Diabetic peripheral neuropathic pain: clinical and quality-of-life issues. In Mayo Clinic Proceedings Elsevier. 2006;81(4): S3S11.

7. Sofaer-Bennett B., Walker J., Moore A., Lamberty J., Thorp T., O'Dwyer J. The social consequences for older people of neuropathic pain: a qualitative study. Pain Medicine 2007;8(3):263-270.

8. Zelman D.C., Brandenburg N.A., Gore M. Sleep impairment in patients with painful diabetic peripheral neuropathy. The Clinical Journal of Pain 2006;22(8):681-685.

9. Boulanger L., Zhao Y., Foster T.S., Fraser K., Bledsoe S.L., Russell M.W. Impact of comorbid depression or anxiety on patterns of treatment and economic outcomes among patients with diabetic peripheral neuropathic pain. Current Medical Research and Opinion 2009;25(7):1763-1773.

10. Ziegler D., Schneider E., Boess F.G., Berggren L., Birklein F. Impact of comorbidities on pharmacotherapy of painful diabetic neuropathy in clinical practice. Journal of Diabetes and its Complications 2014;28(5):698-704.

11. Barrett A.M., Lucero M.A., Le T., Robinson R.L., Dworkin R.H., Chappell A.S. Epidemiology, public health burden, and treatment of diabetic peripheral 
neuropathic pain: a review. Pain Medicine 2007;8(s2),S50-S62.

12. Yang M., Qian C., Liu Y. Suboptimal treatment of diabetic peripheral neuropathic pain in the United States. Pain Medicine 2015;16(11):2075-2083.

13. Jane S.W., Lin M.S., Chiu W.N., Beaton R.D., Chen M.Y. Prevalence, discomfort and self-relief behaviours of painful diabetic neuropathy in Taiwan: a cross-sectional study. BMJ Open 2016;6(10):e011897.

14. Esteve R., Ramírez-Maestre C., LópezMartínez A.E. Adjustment to chronic pain: the role of pain acceptance, coping strategies, and pain-related cognitions. Annals of Behavioral Medicine 2007;33(2):179-188.

15. Haythornthwaite J.A., Benrud-Larson L.M. Psychological aspects of neuropathic pain. The Clinical journal of Pain 2000;16(2): 101-105.

16. Keogh E., Eccleston C. Sex differences in adolescent chronic pain and pain-related coping. Pain 2006;123(3):275-284.

17. Lansbury G. Chronic pain management: a qualitative study of elderly people's preferred coping strategies and barriers to management. Disability and Rehabilitation 2000;22(1-2):2-14.

18. McCracken L.M., Eccleston C. A comparison of the relative utility of coping and acceptance-based measures in a sample of chronic pain sufferers. European Journal of Pain 2006;10(1):23-23.

19. Turk D.C., Okifuji A. Psychological factors in chronic pain: evolution and revolution. Journal of Consulting and Clinical Psychology 2002;70(3):678.

20. Turk D.C., Audette J., Levy R.M., Mackey S.C., Stanos S. Assessment and treatment of psychosocial comorbidities in patients with neuropathic pain. In Mayo Clinic Proceedings Elsevier. 2010;85(3):42-50.

21. Eti-Aslan F. ağrı değerlendirme yöntemleri. C.Ü. Hemşirelik Yüksekokulu Dergisi 2002;6(1);9-16.

22. Altunışık R., Coşkun R., Yıldırım E., Bayraktaroğlu S. Sosyal Bilimlerde
Araştırma Yöntemleri. 6. Basım, Sakarya, Sakarya Kitabevi, 2008.

23. Yıldırım A., Şimşek H. Sosyal Bilimlerde Nitel Araştırma Yöntemleri. 10. Basım, Ankara, Şeçkin Yayıncılık, 2006.

24. Afşar F., Pınar R. Kanser Hastalarında Ağrı ve Ağrı İle Baş etme Yöntemlerinin Değerlendirilmesi. Atatürk Üniversitesi Hemşirelik Yüksekokulu Dergisi 2003;6(3):19-28.

25. Barry L.C., Kerns R.D., Guo Z., Duong B.D., Iannone B.P., Reid C. Identification of strategies used to cope with chronic pain in older persons receiving primary care from a Veterans Affairs Medical Center. J Am Geriatr Soc 2004;52(6):950-956.

26. Peres M.F., Lucchetti G. Coping strategies in chronic pain. Current Pain and Headache Reports 2010;14(5): 331-338.

27. Reid M.C., Barry L.C., Kerns R.D., Duong B.D., Concato J. Coping strategies and their associations with levels of disability or pain, among older veterans receiving primary care. J Clin Epidemiol 2002;55(6):629.

28. Ersek M., Turner J.A., Kemp C.A. Use of the chronic pain coping inventory to assess older adults' pain coping strategies. J Pain 2006;7(11):833-842. 